Journal of Biotechnology 17(4): 673-688, 2019

\title{
USING ARACHIS PINTOI LEAF EXTRACTS IN BIOSYNTHESIS OF SILVER NANOPARTICLES FOR IMPROVING THE VASE LIFE OF CUT CARNATION DIANTHUS CARYOPHYLLUS L.
}

\author{
Tran Lap Xuan, Le Ba Le, Le Thi Anh Tu ${ }^{\bowtie}$ \\ Da Lat University, Lam Dong, Viet Nam \\ ${ }^{\square}$ To whom correspondence should be addressed. E-mail: tulta@dlu.edu.vn
}

Received: 01.10.2018

Accepted: 19.12.2019

\section{SUMMARY}

\begin{abstract}
A biological method for synthesizing silver nanoparticles (SNPs) using the leaf extracts of Arachis pintoi Krapov. \& W.C. Greg. was developed. The optimum conditions of input materials were found with leaf autoclaving in $15 \mathrm{~min}, 20 \mathrm{~g}$ fresh leave, and $4 \mathrm{mM}$ of silver nitrate $\left(\mathrm{AgNO}_{3}\right)$. To study the role of time, temperature, and solution $\mathrm{pH}$ of the reaction, varying time reaction $(5,30,60,90,120,150$, and $180 \mathrm{~min})$, temperature reaction $\left(10,20,30,40\right.$, and $\left.50^{\circ} \mathrm{C}\right)$ and $\mathrm{pH}$ of the solution $(1,3,5,7,9$, and 11) were investigated. The optimal biosynthesis conditions were achieved in $180 \mathrm{~min}$ of reaction time at $50^{\circ} \mathrm{C}$ and $\mathrm{pH} 11$. The obtained nanoparticles have spherical and oblong in shape with average size of $26.4 \mathrm{~nm}$. The SNPs in 4 concentrationss $(5,15,25$, and $35 \mathrm{ppm})$ combined with and without $2 \%$ sucrose extended vase life, enlarged flower diameter, and maintained increase the relative fresh weight with vase solution uptake rate. SNPs inhibited significantly the bacterial growth in the stem end and vase solution, reduced the blockage in stems and therefore promoted the postharvest quality of carnation cut flowers. Out of the treatments, administration of $5 \mathrm{ppm}$ SNPs with $2 \%$ sucrose of vase solution gave the best results for all parameters. The biosynthesis SNPs could be applied as a promising preservative solution for carnation cut flowers.
\end{abstract}

Keywords: Arachis pintoi, biosynthesis, carnation, cut flowers, preservative, silver nanoparticles

\section{INTRODUCTION}

Carnation (Dianthus caryophyllus L.) is one of the most popular cut flowers in the world. It's a member of the family Caryophyllaceae and belongs to the genus Dianthus (Galbally, Galbally, 1997; Jurgens et al., 2003). Carnations own the excellent quality, wide range of colors, forms, ability to withstand long distance transportation and rehydrate after continuous shipping (Basavaraj, Hermla, 2014). The balance between water uptake and water loss determine the quality and longevity of cut flowers (Lu et al., 2010a; Da Silva, 2003; He et al., 2006). There are three types of stem end blockage including physical air emboli (Van Meeteren, 2006), physical wound -induced (Williamson et al., 2002; He et al., 2006; Loubaud, Van Doorn, 2004), and microbial contamination (Liu et al., 2009b; Put, 1990). Microbes can also secrete extracellular virulence factors including enzymes, hormones or toxic compounds (Buttner, Bonas, 2010; Salmond, 1994) produce ethylene (Williamson et al., 2002) to accelerate senescence. Vascular occlusions and associated wilting in cut carnation (Dianthus caryophyllus L.) usually occurred when the number of bacteria in vase water reached $10^{7}-10^{11}$ colony forming units (CFU/ml) (Edrisi et al., 2011; Rahman et al., 2012).

There is a need to extend vase life in the economically significant cut flowers. One of the proper ways to extend the vase life of cut flowers is to treat them with various chemicals instantly after harvest such as silver thiosulphate (STS) (Nowak, Rudnicki, 1990), gibberellins (GA) (Hamidimoghadam et al., 2014) and cytokinins (CK), accel (BA+GA4+7) (Mutui et al., 2001) and thidiazuron (TDZ) (Ferrante et al., 2002). Supply of chemicals associated with alleviation of bacterial accumulation at the stems (Hamed et al., 2013; Van Doorn et al., 1991) and inhibition of suberin synthesis (Williamson et al., 2002), then increased 
the vase life. A drawback of this supply is the high concentrations that lead to the phytotoxic (Nell, 1992; Van Doorn, 2012). As the novel antiseptic, silver nanoparticles (SNPs) have become common use in pharmaceutics, cosmetics, textile, water purification, and vegetable disinfection applications (Jiang et al., 2006; Patra, Baek, 2017; Usha, Rajasekharreddy, 2011). Morones et al. (2005) reported that SNPs can kill 650 species of bacteria in water. SNPs caused the decrease of cell membrane permeability by releasing mono valent silver ions $\left(\mathrm{Ag}^{+}\right)$which replace the hydrogen cation $\left(\mathrm{H}^{+}\right)$of sulfhydryl or thiol groups (-SH) on surface proteins in bacterial cell membranes (Feng et al., 2000). SNPs have been an effective antimicrobial agent (Solgi et al., 2009; Liu et al., 2009a), an ethylene inhibitor (Kim et al., 2005) and/or a regulator of stomatal aperture (Lu et al., 2010b). SNPs inhibited the growth of bacteria-related blockage in cut roses (Li et al., 2012; Lu et al., 2010b; Ohkawa et al., 1999), cut gerbera flowers and cut Acacia holosericea (Liu et al., 2009b) and extended their vase life.

There have been some reports on treatments of SNPs to prolong the vase life of carnation cut flowers (Hamidinoghadam et al., 2014; Hashemabadi et al., 2014). However, most of the study uses the commercial SNPs or chemically synthesized particles. A little has been reported on SNPs synthesized with plant extracts on the vase life (Solgi et al., 2011). The biosynthesis of SNPs from plant extracts has been reported to be economically efficiency and nontoxic to the environment (Yasin et al., 2013). SNPs can be produced at low concentration of variety of leaf extracts without using any additional harmful chemical/physical methods (Ahmed et al., 2015) such as particularly neem leaf broth (Azadirachta indica), Pelargonium graveolens, geranium leaves, Medicago sativa (Alfalfa), Aloe vera, and Emblica officinalis (Amla, Indian Gooseberry) (Hamed et al., 2013). Till date, no study was reported for the synthesis of SNPs using the Pinto peanut (Arachis pintoi Krapov. \& W.C. Greg.)

Arachis pintoi Krapov. \& W.C. Greg. is grown as a permanent pasture in intensive grazing systems and in very shaded situations under plantation crops where annual rainfall is above $1100 \mathrm{~mm}$. It is cultivated as a ground cover or as an ornament and improving soils and degraded pastures (Cab Jiménez et al., 2008; Cook et al., 2005). The presence of flavonoids, tannin, and phytosterol has been detected in Arachis species extracts (Grosso et al., 2000; Lopes et al., 2011). These phytocompounds play a role of reduction of silver ions into silver nanoparticles and stabilizing SNPs to prevent agglomeration (Medda et al., 2015; Raja et al., 2017; Yugandhar et al., 2016). Many study revealed that the extract from the leaves have high antioxidant capacity and antibacterial activity (De SousaMachado et al., 2018; Sang et al., 2014). The aim of this study was to investigate the Arachis pintoi leaf extracts-mediated biosynthesis of SNPs and their effects on some bacteria which are involving in decreasing the flower longevity in order to find the proper method to extend the vase life and keep postharvest quality of carnation cut flowers.

\section{MATERIALS AND METHODS}

\section{Materials}

The fresh leaves of Arachis pintoi Krapov. \& W.C. Greg. were collected from Dalat, Lamdong, Vietnam. The leaves were washed thoroughly 3 times with tap water and twice with sterile water. The fresh leaves were dried at room temperature and finely ground for synthesis SNPs. The voucher specimen is available from the resoures unit of Herbarium of Dalat Univeristy, Lamdong, Vietnam.

The carnation (Dianthus caryophyllus L.) cut flowers were obtained from a commercial greenhouse at their optimum developmental stage with the uniformity size, color and lack of defects. Flowers were placed immediately in water bucket, covered with a plastic film and transported to the laboratory. Stems were re-trimmed to a length of 20 $\mathrm{cm}$ (under deionized water). The experiments were carried out at the same day.

\section{Synthesis of SNPs}

Fresh leaves of $A$. pintoi were finely ground and added to $200 \mathrm{~mL}$ of distilled water. The different methods to prepare leaf extracts including heating at the different time period of 5, 10, 15, 20, $25 \mathrm{~min}$ at $60^{\circ} \mathrm{C}$ with continuous stirring or autoclaving at 121 ${ }^{\circ} \mathrm{C}$ at $15 \mathrm{lbs}$ psi for $15 \mathrm{~min}$. The mixture was cooled down and then filtered with the Whatman paper number 1. Filtrate was collected. The varied initial weight of fresh leave on synthesis of $\operatorname{SNPs}(5,10$, $15,20,25 \mathrm{~g})$ were prepared. Effect of time on the biosynthesis of SNPs under the optimum conditions (including the initial weight of fresh leave and the method to extraction) was measured at the different 
time interval of 5, 30, 60, 90120,150 and $180 \mathrm{~min}$. The efficiency of the bio-synthesis also was investigated under various conditions including changing $\mathrm{AgNO}_{3}$ concentration $(1,2,3,4 \mathrm{mM})$, the $\mathrm{pH}(1,3,5,7,9,11)$, and temperature of the reaction $\left(5,20,30,40\right.$, and $\left.50^{\circ} \mathrm{C}\right)$.

The silver ions reduced to SNPs can be observed by the gradual change in color of the solution. The final reaction mixture was purified by cetrifugation at $9000 \mathrm{rpm}$ for $30 \mathrm{~min}$. Supernatants were discarded and the pellet was redispersed in de-ionized water to eliminate any contaminating plant material before centriguge at $9000 \mathrm{rpm}$ for $60 \mathrm{~min}$. This wash step was repeated twice to remove water-soluble biological residues. The pellet was dried at $37^{\circ} \mathrm{C}$ for $24 \mathrm{~h}$ to determine the dry mass of SNPs for yield analysis. The relationship between the coressponding the dry mass and the volume of mixture of the SNPs synthesized at the optimum conditions were determined.

\section{Characterization of SNPs}

The bio-reduction of SNPs was determined using UV-Vis spectrophotometer. The absorbance spectrum of the sample was obtained in the range of $400-700 \mathrm{~nm}$ wavelength, using a UV-Vis spectrometer (Specord 200 plus, Jena, Germany) with distilled water as a reference. SNPs prepared under optimal conditions were centrifuged at 10000 rpm for $20 \mathrm{~min}$ and the pellet was collected, freezedried to obtain a dried powder which was subjected to study the size and shape of the nanoparticles by a transmission electron microscope (TEM). TEM measurements were done by JEOL JEM-1010, operating at $100 \mathrm{kV}$. The TEM grid was prepared by placing a drop of the bio-reduced diluted solution on a carbon-coated copper grid and later drying it under a lamp.

\section{Effects of SNPs on vase life}

The flowers were placed in the bottles containing $100 \mathrm{~mL}$ of preservative solution SNPs. The mouths of bottles were covered with nonabsorption cotton to minimize evaporation loss and prevent contamination. Solution contains the following treatments and remains until the end of vase life: T1: SNPs of 5, 15, 25, 35 ppm, T2: SNPs of $5,15,25,35 \mathrm{ppm}+$ sucrose $2 \%$, T3: Water (filtered through the membrane filter with the pore size of $0.2 \mu \mathrm{m}$ ) - the control, T4: Water (filtered through the membrane filter with the pore size of 0.2 $\mu \mathrm{m})+$ sucrose $2 \%$.

\section{Measurement}

Vase life: Vase life was considered to have ended when visible of $20 \%$ petal color fading

Vase solution uptake: Vase solution uptake was calculated in the vase containing $100 \mathrm{~mL}$ of solution after 10 days. The weights of vase without the cut flowers were recorded after 10 days. The average of 5 replication values was used. The vase solution uptake after 10 days was calculated by the formula:

$$
\mathrm{WU}_{10}(\mathrm{~g} / \text { stem })=\left(\mathrm{S}_{1}-\mathrm{S}_{10}\right)-\left(\mathrm{S}_{1 \mathrm{c}}-\mathrm{S}_{10 \mathrm{c}}\right)
$$

Where $\mathrm{S}_{1}$ is the weight vase of solution $(\mathrm{g})$ at the initial day, $\mathrm{S}_{10}$ is the weight of vase solution $(\mathrm{g})$ on the $10^{\text {th }}$ day, $\mathrm{S}_{1 \mathrm{c}}$ is the weight vase of solution $(\mathrm{g})$ without flowers at the initial day, and $S_{10 c}$ is the weight of vase solution $(\mathrm{g})$ without flowers on the $10^{\text {th }}$ day (He et al., 2006).

Relative fresh weight: The relative fresh water (RFW) of cut flowers was calculated using the following formula:

$$
\mathrm{RFW}(\%)=\left(\mathrm{FW}_{\mathrm{t}} / \mathrm{FW}_{0}\right) \times 100
$$

Where $\mathrm{FW}_{\mathrm{t}}$ is the fresh weight of stem $(\mathrm{g})$ at $\mathrm{t}=$ days $0,1,2$, etc., and $\mathrm{FW}_{0}$ is the fresh weight of stem (g) at $\mathrm{t}=$ day 0 (He et al., 2006).

Flower diameter: The flower diameter was measured as an index for blossom expanding rate. The outer diameter of opened flowers was measured by a caliper in millimeter.

Bacterial counts: Bacterial solution populations were determined by spread the aliquots of vase solutions on LB agar and incubated at $30^{\circ} \mathrm{C}$ for 48 hours (Liu et al., 2009b) to count the total colony. To determine bacterial population in the stem-end, $3 \mathrm{~cm}$ long stem-end segments were trimmed, washed with distilled water twice and chopped to small pieces with sterile secateurs. These pieces were placed in the sterilized tube containing $1 \mathrm{~mL}$ of sterile $0.9 \%$ saline and vortexed in $1 \mathrm{~min}$. The aliquot of the extracts was spread onto LB agar plates. Bacterial colonies were determined as described above.

\section{Statistical analysis}

One-way analysis of variance (ANOVA) and ttest were performed using Excel 2011 statistical tools. A P-value $<0.05$ was used as a criterion for significance level. ANOVA was used to determine whether bactericidal activity of SNPs and 
preservative ability from the different conditions (concentrations and with/without sucrose) are statistical different.

\section{RESULTS AND DISCUSSION}

\section{Effect of methods to prepare leaf extracts on synthesis of SNPs}

The bio-reduction of silver ions to SNPs was optically approved by color changes to yellow or brown (Rani et al., 2011). The formation of colloidal SNPs was monitored by measuring the UV-Vis spectrum that showed strong evidence of colloidal metal particle formation, and the productivity growth in the synthesis medium was indicated by the gradual increase in the absorbance values (Bogireddy et al., 2016). The different methods to prepare leaf extracts were optimized for biosynthesizing SNPs including heating at $60^{\circ} \mathrm{C}$ and autoclaving at $121{ }^{\circ} \mathrm{C}$ at $15 \mathrm{lbs}$ psi (Figure 1). The absorption observed at the range of $433-436 \mathrm{~nm}$ in UV-Vis spectrum which falls between a typical SPR band of spherical SNPs (400 - $450 \mathrm{~nm}$ ) for all treatments. No other measurable peak was observed in the spectrum which confirms that the synthesized products are SNPs only. Appearance of this peak, assigned to a surface plasmon, is well-documented for various metal nanoparticles with size less than $100 \mathrm{~nm}$ (Henglein, 1993). The absorbance increased with the increasing heating time to autoclaving treating.

The color of the solution changed from yellow to brownish color on increasing heating time to autoclaving treating due to the number of $\mathrm{Ag}^{+}$ions that have been reduced to zero-valent $\mathrm{Ag}^{0}$ atoms and the number of SNPs of smaller sizes increased (Saion et al., 2013). The absorption intensity demonstrated that autoclaving treating yielded a larger amount of SNPs.

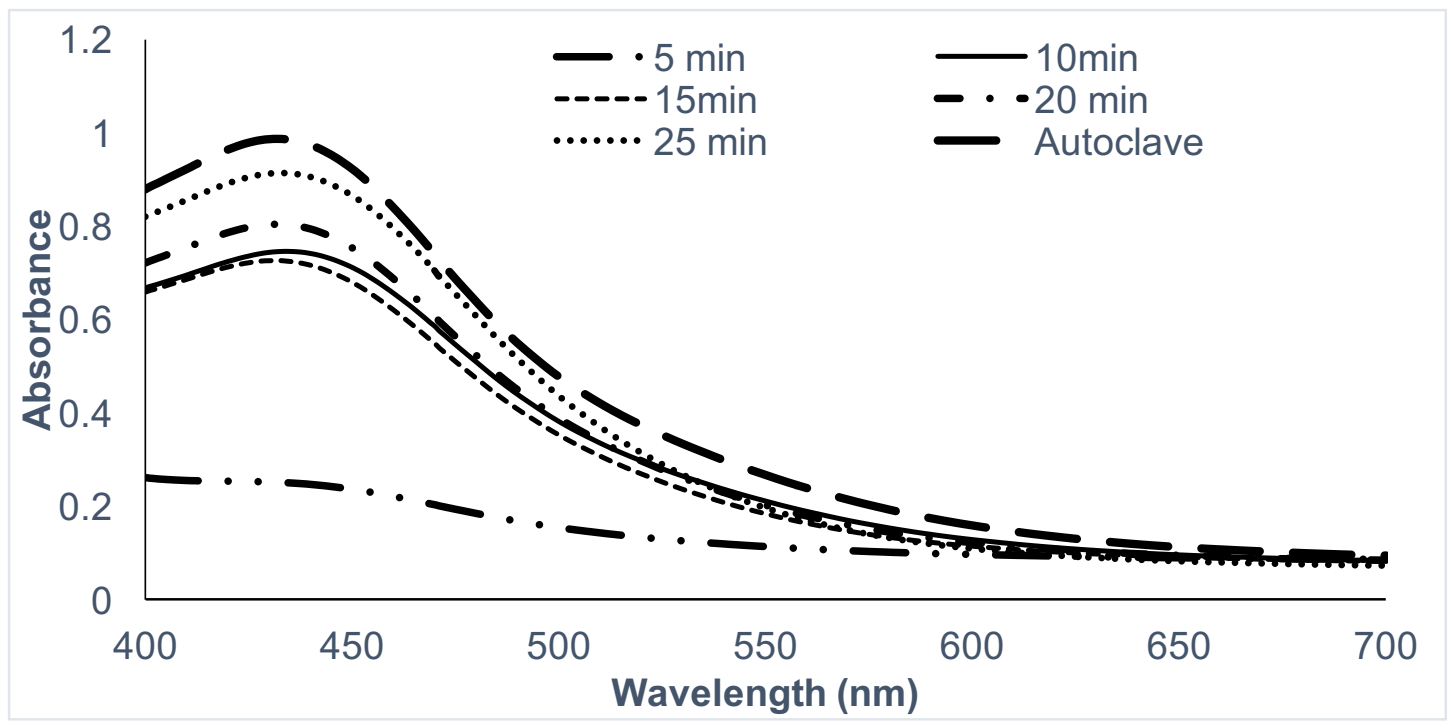

Figure 1. Effects of the heating methods of $5,10,15,20$ and $25 \mathrm{~min}$ at $60^{\circ} \mathrm{C}$ and autoclaving at $121{ }^{\circ} \mathrm{C}$ at $15 \mathrm{lbs}$ psi on synthesis of SNPs using UV-Vis spectroscopy measurement.

\section{Effect of the initial weight of fresh leave on synthesis of SNPs}

The UV-Vis spectroscopy is a sensitive method to detect the formation of the SNPs (Gao et al., 2016; Kim et al., 2003). The different initial fresh leaf weight to prepare leaf extracts was also characterized for biosynthesis. The peak positions of the surface plasmon resonances (SPRs) were 436, $434,439,437$ and $438 \mathrm{~nm}$ of wavelength and the maximum absorbance were $0.6112,0.7874,1.5801$,
1.6765 , and 1.4947 in the experiments of $5,10,15$, 20 and $25 \mathrm{~g}$ fresh leave for extraction, respectively. The formation of SNPs was confirmed by the SPRs in the range of $350 \mathrm{~nm}$ to $600 \mathrm{~nm}$ (Henglein, 1993). No SRPs at more than $500 \mathrm{~nm}$ in Figure 2 indicated that most obtained SNPs have small size and similar shape (Saion et al., 2013). Birla et al. (2013) reported that the intensity of the plasmon peak increased with the increasing concentration of SNPs. The similar trend was observed by Mukherjee et al. 
(2008). Figure 2 shows a gradual increase in the absorption intensity when increasing the initial weight of fresh leave. The localised SPR peak is more pronounced for SNPs prepared using $20 \mathrm{~g}$ fresh leave.

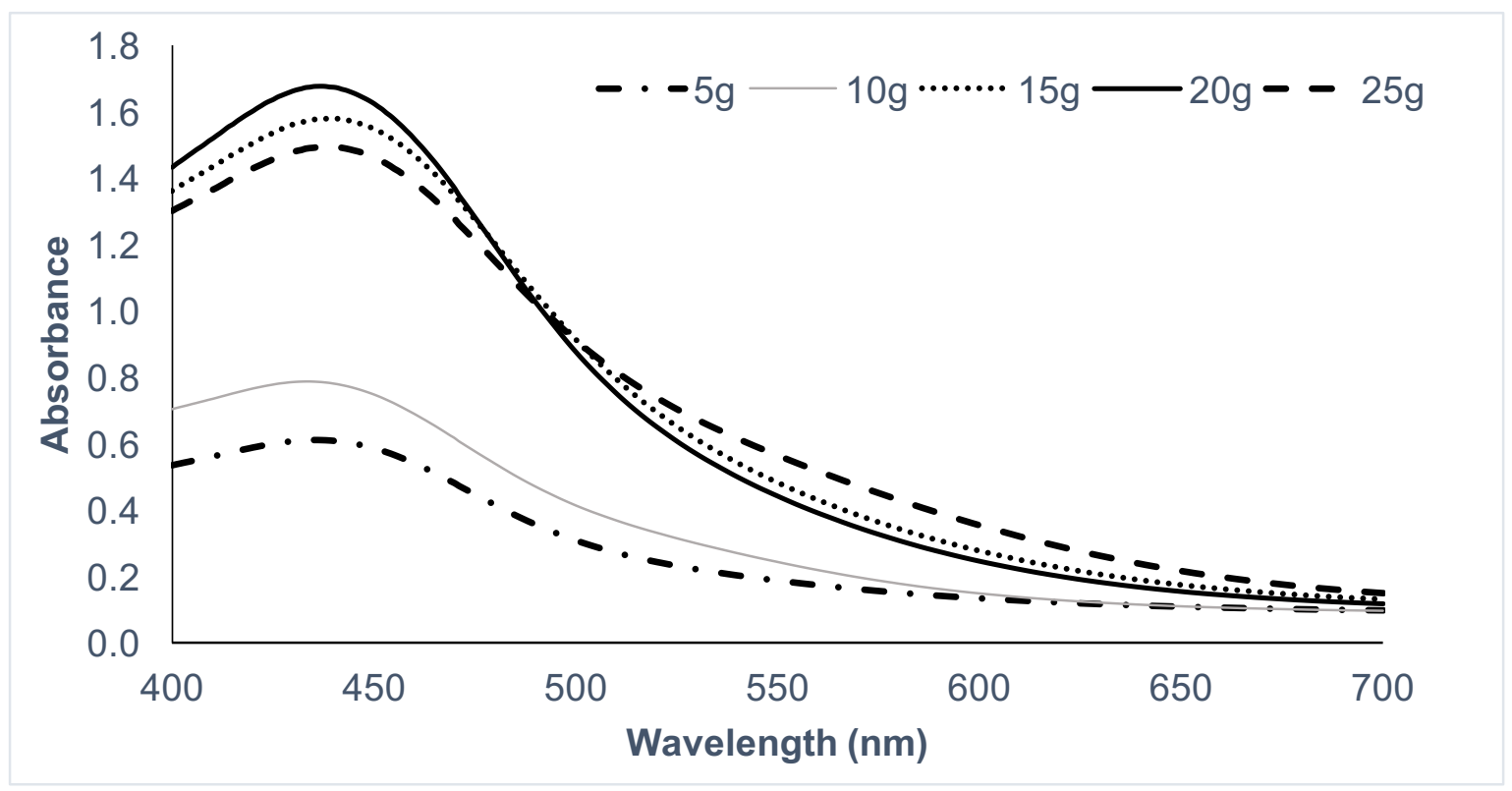

Figure 2. Effects of the initial weight of 5, 10, 15, 20 and $25 \mathrm{~g}$ fresh A. pintoi leave on synthesis of SNPs using UV-Vis spectroscopy measurement.

\section{Effect of time on synthesis of SNPs}

Figure 3 depicts the UV-Vis spectra of SNPs with a range of the time required for the completion of the reaction. Change in color of the reaction mixture was observed after $5 \mathrm{~min}$. Accordingly, all the spectra except for $5 \mathrm{~min}$ duration have an intense peak ranging from 434 to $470 \mathrm{~nm}$. The absorption peak blue shifted toward the lower wavelength with increasing the time reaction to decrease particle size (Saion et al., 2013). During the whole reaction process, the shift of the peak positions and the shape of the absorption spectra show that at the beginning a small volume of small size particles were formed and then the small particles aggregated to the large particles. After $120 \mathrm{~min}$ the large particles decomposed to the small ones. The optimum time for the reaction from this study is $180 \mathrm{~min}$ and no further change in color was observed after this time (Figure 3). Dinesh et al. (2012) reported the completion reduction of $\mathrm{AgNO}_{3}$ using the aqueous park extracts of $H$. antidysenterica after $120 \mathrm{~min}$, while the reduction reaction of Azadirachta indica leaf extracts with $\mathrm{AgNO}_{3}$ completed after half of hour (Shankar et al., 2004). This also shows that the plant species had significant influences on the time reaction to synthesize SNPs.

Effect of the metal ion concentrations on synthesis of SNPs

The effect of metal ion concentrations was investigated by varying $\mathrm{AgNO}_{3}$ concentrations from 0.5 to $4 \mathrm{mM}$. The change of the mixture to brownish color was found in all experiments. At the low silver ion concentration, the absorbance was less than the higher metal ion concentrations (Figure 4). Sharp plasmon peaks displayed in the Figure 4 is observed from $430 \mathrm{~nm}$ to $453 \mathrm{~nm}$, as expected for SNPs. The $\mathrm{UV}-\mathrm{Vis}$ spectra indicated that increasing $\mathrm{AgNO}_{3}$ concentrations led to form more SNPs.

\section{Effect of pH on synthesis of SNPs}

$\mathrm{pH}$ is one factor which affects the synthesis of SNPs. Change of the $\mathrm{pH}$ of the reaction mixture affects the charge of biomolecules which may alter the formation and stability of SNPs (Verma, Mehata, 2016). The peak position and intensity on varying the 
$\mathrm{pH}$ of the solution show in the Figure 5. At low $\mathrm{pH}$ ( $\mathrm{pH} 1$ ), a flat UV-Vis spectrum was observed. When $\mathrm{pH}$ increased from 3 to 7 , absorption peaks increased. The UV-Vis spectra at $\mathrm{pH} 3,5,7,9$, and 11 were 442 $\mathrm{nm}, 434 \mathrm{~nm}, 432 \mathrm{~nm}, 434 \mathrm{~nm}$, and $438 \mathrm{~nm}$, respectively. As the $\mathrm{pH}$ increased from 3 to 7 , the size of SNPs decreased. However, when increase the $\mathrm{pH}$ from 9 to 11, the energy required for excitation of surface plasmon electrons decreases, thus the absorption maximum shifted towards the longer wavelength regions. This was the evidence that the size of the SNPs increased when the $\mathrm{pH}$ shifted from 9 to 11. Gane et al. (2012) demonstrated that a large number of functional groups in lightly acidic $\mathrm{pH}$ mixture enhances the number of $\mathrm{Ag}$ ions to bind and then formed a larger number of SNPs with smaller diameters. The negative ions in a basic medium amplify the reduction of $\mathrm{Ag}^{+}$into SNPs. The diffusion between adjacent adsorption sities on a surface of $\mathrm{Ag}$ atoms at a higher ion density increases and lead to form bond with nearest neighbor atoms (Ball et al., 1987). This leads to form the SNPs with a larger size. However, there was a lightly different in the absorption peak.

The absorption intensity increased with increasing $\mathrm{pH}$ from 3 to 11 . At the $\mathrm{pH} 11$, the highest absorption intensity indicated that a largest number of SNPs were synthesis. Thus, $\mathrm{pH} 11$ was the optimum $\mathrm{pH}$ for biosynthesis of SNPs from $A$. pinto leaf extracts to obtain the appropriate SNPs in term of size and yield for later application. Khalil et al. (2013) reported that the absorbance of the SNPs synthesized from olive leaf extracts increased with the increasing $\mathrm{pH}$ from 2 to 8 while Vanaja et al. (2012) stated that the alkaline $\mathrm{pH}$ was more favorable for forming SNPs. The inconsistence may be the results of the leave resources and conditions to synthesis.

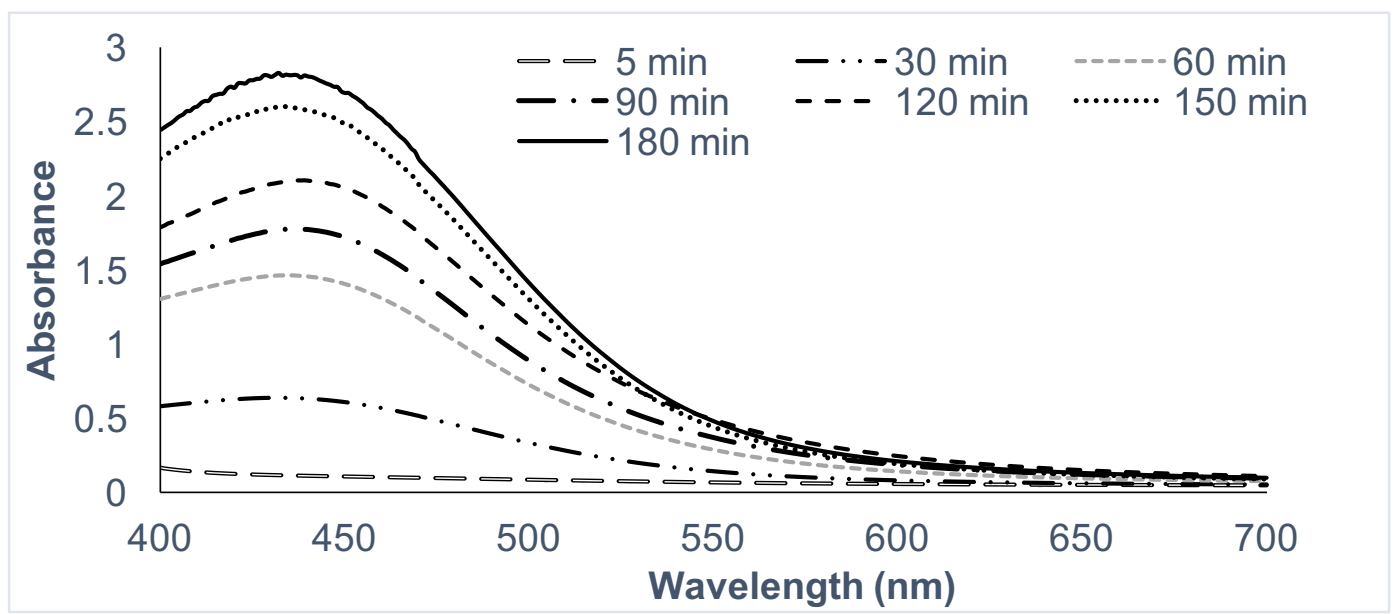

Figure 3. Effects of the time reaction of $5,30,60,90,120,150$ and $180 \mathrm{~min}$ on synthesis of SNPs using UV-Vis spectroscopy measurement.

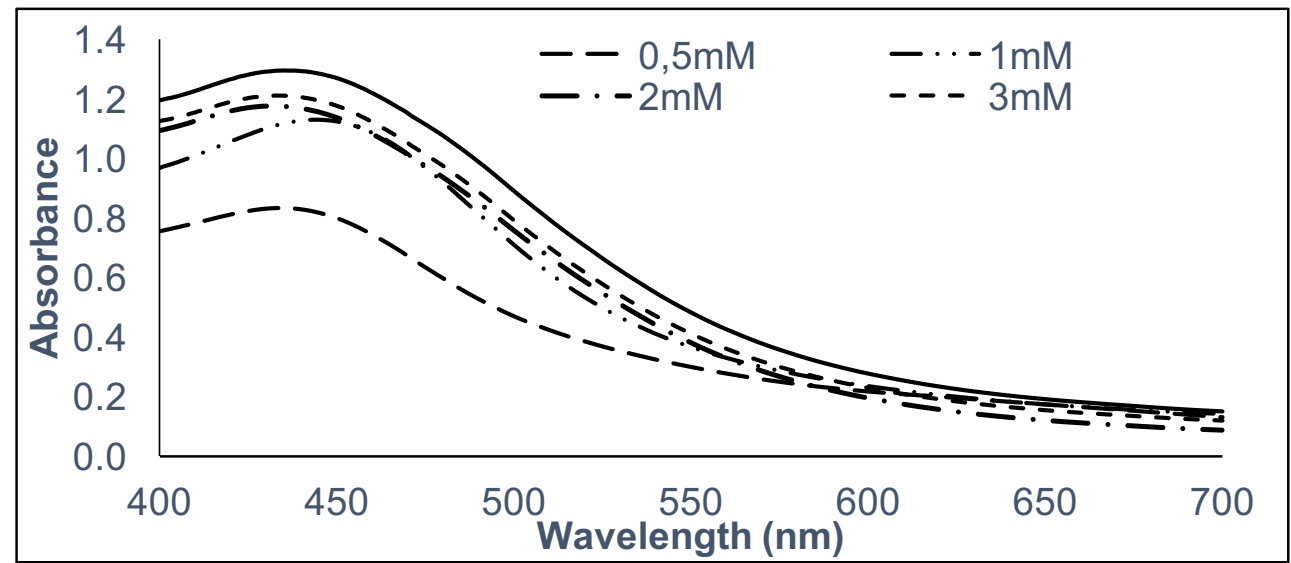

Figure 4. Effect of metal ion concentrations $(0.5,1,2,3$ and $4 \mathrm{mM})$ on synthesis of SNPs using UV-Vis spectroscopy measurement. 


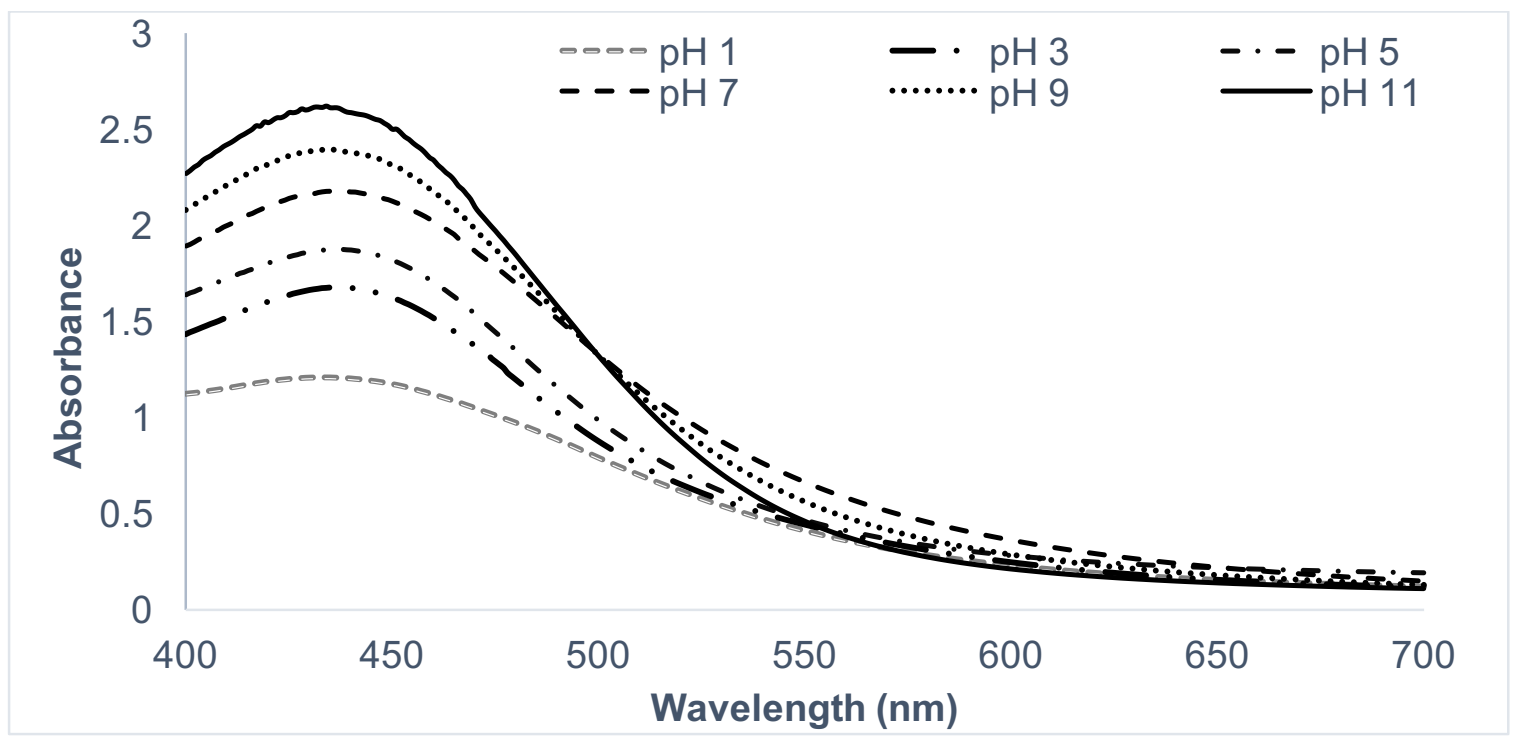

Figure 5. Effect of $\mathrm{pH}$ of $1,3,5,7,9$, and 11 on synthesis of SNPs using UV-Vis spectroscopy measurement.

\section{Effect of temperature on synthesis of SNPs}

Another parameter which affects the formation of SNPs is the temperature. The absorption peaks of the SNPs prepared at different temperatures $\left(10\right.$ to $\left.50^{\circ} \mathrm{C}\right)$ while keeping the above optimum conditions constant display in Figure 6. The absorption peaks observed at $10^{\circ} \mathrm{C}$ to $50^{\circ} \mathrm{C}$ shifted toward blue from 451 to $426 \mathrm{~nm}$. $\mathrm{UV}$-Vis spectra shifted toward lower wavelength as the temperature increased as the results of the formation of smaller size SNPs. As the increase the temperature, the increasing kinetic energy of the molecules may lead to the consuming silver ions faster, and then smaller particles of the uniform size are formed (Verma, Mehata, 2016). The rapid nucleation process of metallic nanoparticles involving the enhanced consumption of the metal ions with least secondary reduction of the preformed nuclei tends to occure at the high reaction temperature (Dwivedi, Gopal, 2010). This results are agreement with the previous studies (Verma, Mehata, 2016; Ibrahim, 2015; Dinesh et al., 2012; Traiwatcharanon et al., 2017). Further, the higher temperature enhanced the rate of the biosynthesis as the color change was observed after few minutes when $\mathrm{AgNO}_{3}$ mixed with the leaf extracts.

\section{Yield analysis}

The concentration of SNPs synthesized at the optimum conditions was determined on a $\mathrm{mg} / \mathrm{ml}$ from the final reaction mixture. The final reaction mixture volume is linearly related to the yield of the SNPs dry mass with $\mathrm{R}^{2}=0.9893$. The yield of biosynthesis SNPs at the optimum conditions was $0.5195 \mathrm{mg} / \mathrm{mL}$.

\section{Morphology of SNPs}

Transmission electron microscopy (TEM) technique was used to visualize the size and shape of synthesized SNPs through leaf extracts of $A$. pinto $i$ under optimum conditions. The TEM image reveals a mixture of small and bigger synthesized SNPs (Figure 8A). The biosynthesized SNPs were spherical and oblong in shape. The size of particles distributed in the range of 5 to $65 \mathrm{~nm}$ with the average particle diameter of $26.4 \mathrm{~nm}$ (Figure 8B).

\section{Vase life}

Results in Table 2 show that all SNP treatments enhanced the vase life of carnation flowers ( $\mathrm{P} \leq$ $0.05) \leq 0.05)$. With the treatments without sucrose, the $5 \mathrm{ppm}$ SNP treatment gave a significant difference compared to the control (filtered water). Comparing the treatments with only SNPs, the 35 ppm SNP treatment had the longest vase life (16.8 days). Increasing SNP concentrations led to prolong the vase life of carnation cut flowers. This result is in agreement with the previous studies on other cut flowers such as Polianthes tuberose (Hutchinson et al., 2004), 'Cherry Brandy' rose (Jowkar et al., 2013) and Tulipa spp. (Bowyer et al., 2003). However, Carrillo-López et al. (2016) reported that, 
the low concentrations of SNPs favored for vase life. The inconsistence may be the results of different types of SNPs including the size and shape.

The combination of SNPs with $2 \%$ sucrose increased the vase life. Sucrose is generally used to sustain metabolic activity. The efficacy of sucrose in prolonging vase life and delaying cut flower senescence has been reported for rose, lily, peony, sweet pea, orchid, and carnation (Ichimura, Suto, 1999; Chen et al., 2001; Verlinden, Garcia, 2004; Hoeberichts et al., 2007; Arrom, Munne-Bosch, 2012; Zhang et al., 2012). The treatments of SNPs with $2 \%$ sucrose exhibited statistically significant differences compared to the control. Safa et al. (2012) reported that SNPs have the potential to extend vase life and enhance the postharvest quality of cut Gerbera cv. "Balance" flowers. Nevertheless, there was no significant difference between all treatments with SNPs plus 2\% sucrose in term of the vase life. The data shows that the efficiency of the solution included the antibacterial activity of SNPs and sustaining metabolic activity of sucrose. Hatami et al. (2013) revealed that SNPs plus sucrose significant extended the vase life because of increasing hydraulic conductance related to the high leaf water content.

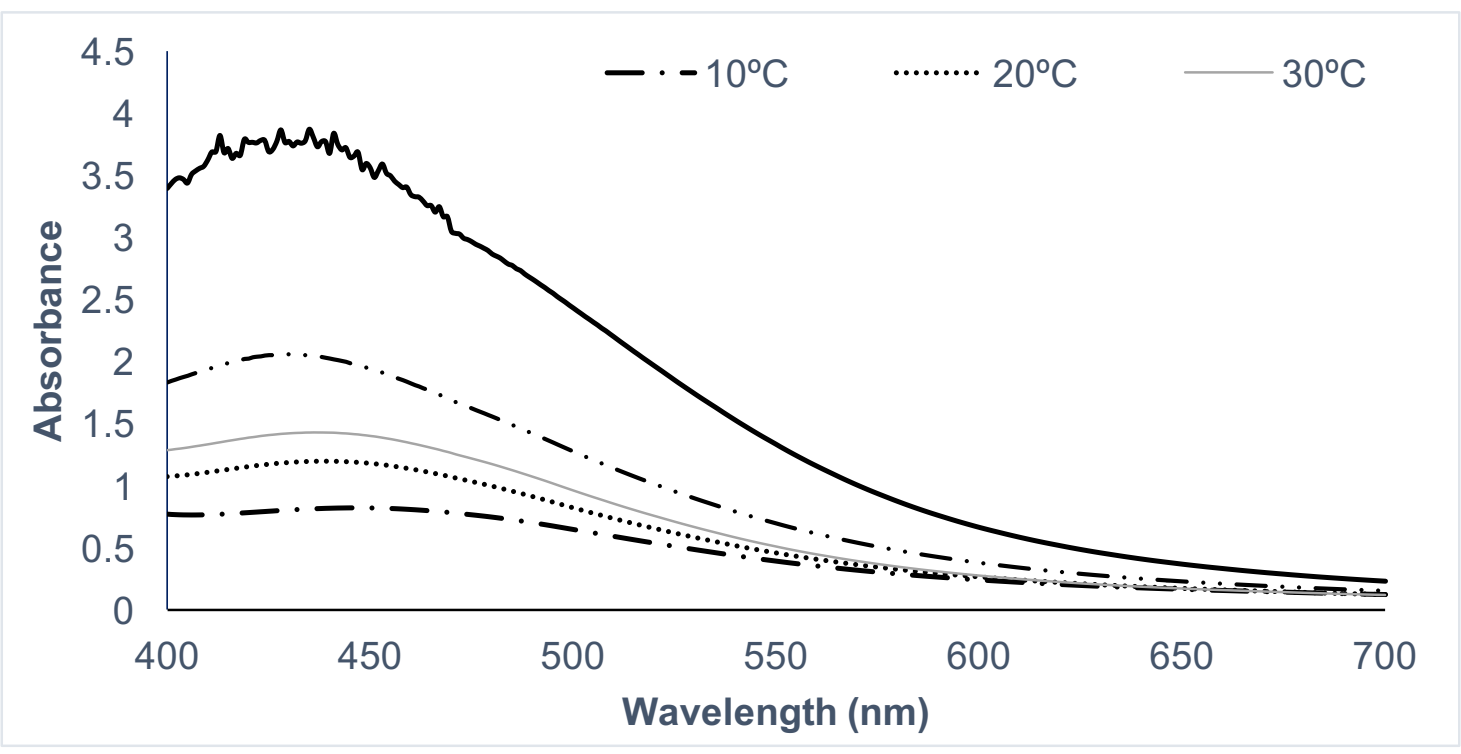

Figure 6. Effect of temperature $\left(10,20,30,40\right.$, and $\left.50^{\circ} \mathrm{C}\right)$ on synthesis of SNPs using UV-Vis spectroscopy measurement.

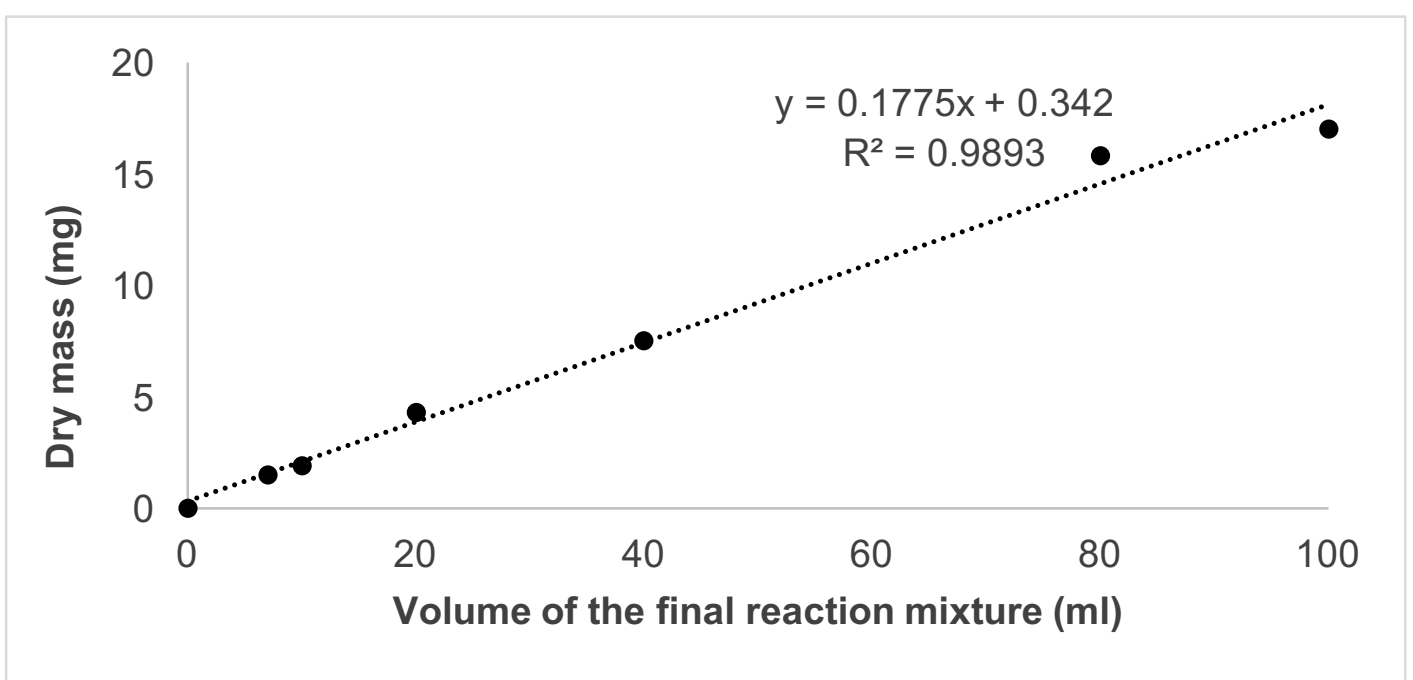

Figure 7. Relationship between the volume of the final reaction mixture and SNPs dry mass. 

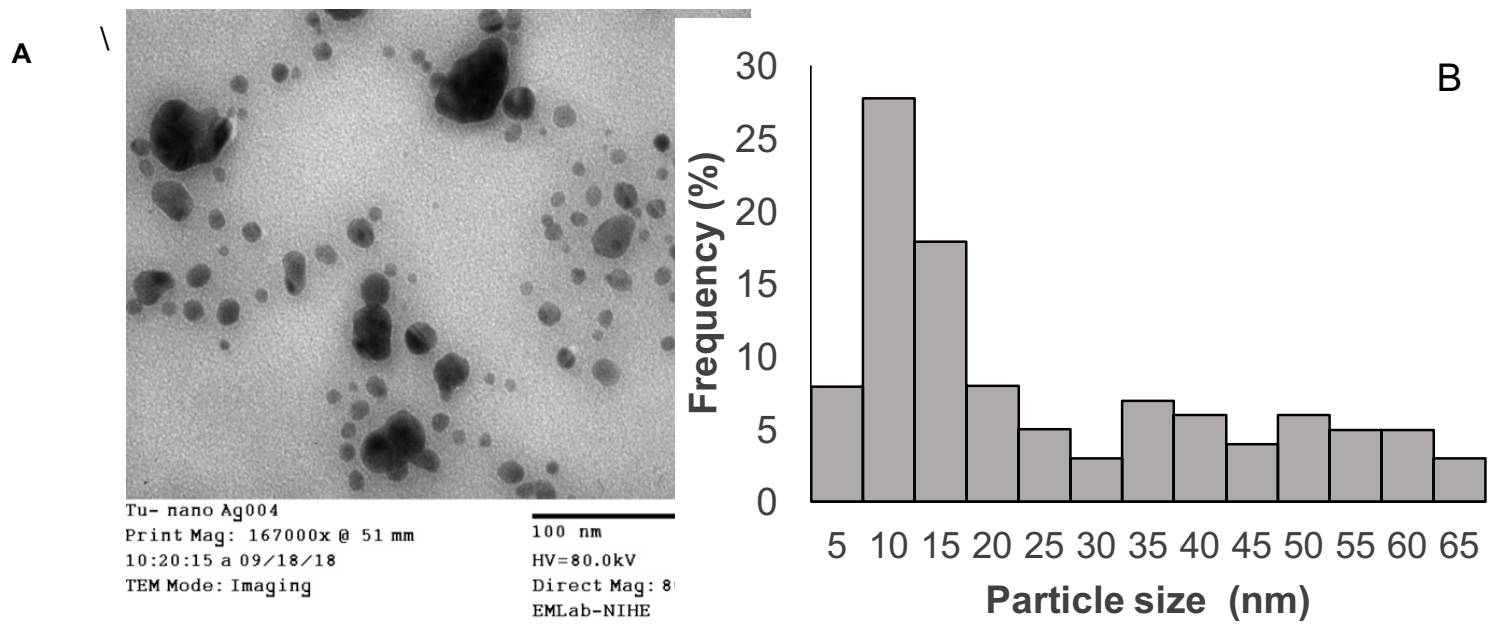

Figure 8. (A) TEM image of the SNPs; (B) Particle size distribution histogram of SNPs.

Table 3. Effect of different treatments of SNPs on vase life.

\begin{tabular}{llll} 
Treatments & Vase life (days) & Treatments & Vase life (days) \\
\hline Filtered water & $9 \pm 0.3 \mathrm{a}$ & Filtered water + Sucrose $2 \%$ & $11 \pm 0.2 \mathrm{f}$ \\
\hline $5 \mathrm{ppm}$ SNPs & $12.4 \pm 0.2 \mathrm{~b}$ & $5 \mathrm{ppm}$ SNPs + Sucrose $2 \%$ & $19 \pm 0.2 \mathrm{~g}$ \\
\hline $15 \mathrm{ppm}$ SNPs & $13.6 \pm 0.3 \mathrm{c}$ & $15 \mathrm{ppm}$ SNPs + Sucrose $2 \%$ & $19 \pm 0.1 \mathrm{~g}$ \\
\hline $25 \mathrm{ppm}$ SNPs & $15.4 \pm 0.1 \mathrm{~d}$ & $25 \mathrm{ppm}$ SNPs + Sucrose $2 \%$ & $19 \pm 0.1 \mathrm{~g}$ \\
\hline $\mathbf{3 5}$ ppm SNPs & $16.8 \pm 0.3 \mathrm{e}$ & $35 \mathrm{ppm}$ SNPs + Sucrose $2 \%$ & $19 \pm 0.15 \mathrm{~g}$ \\
\hline
\end{tabular}

\section{Relative fresh weight and water uptake}

The relative fresh weight (RFW) increased at the beginning of the experiments, and later decreased (Figure 9). Similar patterns of changes were also reported for cut Chrysanthemum cv. Puma (CarrilloLopez et al., 2016), cut rose (Lu et al., 2010b; Alaey et al., 2011). The control had significantly lower weight than treatments. The RFW of treatments of SNPs with sucrose were remained higher than that without sucrose and the control. Sucrose serves as a substrate for respiration and cell wall synthesis and it maintains water balance, all of which should prolong vase life (Carrillo-Lopez et al., 2016; Weiss, 1997).

The antimicrobial effect of SNPs minimized vase life disorders. A variation in term of the evolution of the fresh weight was observed. The control and sucrose treatments gained the highest weight for the first 5 days, while treatments with 5 and $15 \mathrm{ppm}$ SNPs, 25 and 35 ppm SNPs, 5 and 15 ppm SNPs plus sucrose, 25 and 35 ppm SNPs plus sucrose occupied the highest weight after $6,7,7$, and 8 days, respectively. The highest relative fresh weight $(122.6 \%)$ was obtained with the SNPs of 5 ppm plus sucrose at the $7^{\text {th }}$ day. The relative fresh weight were $118.9 \%, 119.5 \%$, and $120.8 \%$ for treatments of $2 \%$ sucrose with SNPs of $15,25,35$ ppm, respectively.

The result of the water consumption after 10 days was displayed in the Figure $10(\mathrm{P} \leq \leq 0.05)$. SNPs enhanced the absorption of vase solutions. There is significant difference between the water uptake of control and treatment of SNPs with or without sucrose. The water uptake increased when SNP concentrations increased in the experiments with only SNPs. The results are in good agreement with the study of Nemati et al. (2013). The introduction of SNPs as a senescence delaying compound and effective on the loss of fresh weight led to the positive impact on water uptake enhancement which ultimately keeps fresh weight. 
However, the trend was different in the treatments with SNPs plus sucrose. The water uptake of treatments of 5, 15, 25, 35 ppm SNPs with sucrose was not significant different. This result is in agreement with the results of the vase life. In addition, the xylem which is mainly responsible for water transport to the flowers were observed on the days 0 and 10 (Figure 11). The biofilm formation and bacterial blockage were observed at the xylem after 10 days of flowers in the filtered water. Meanwhile, very least bacteria were observed in the xylem vessel walls of flower stems treated with SNPs. There was no stem breakage for SNPs or the combination of sucrose with SNP treatments.

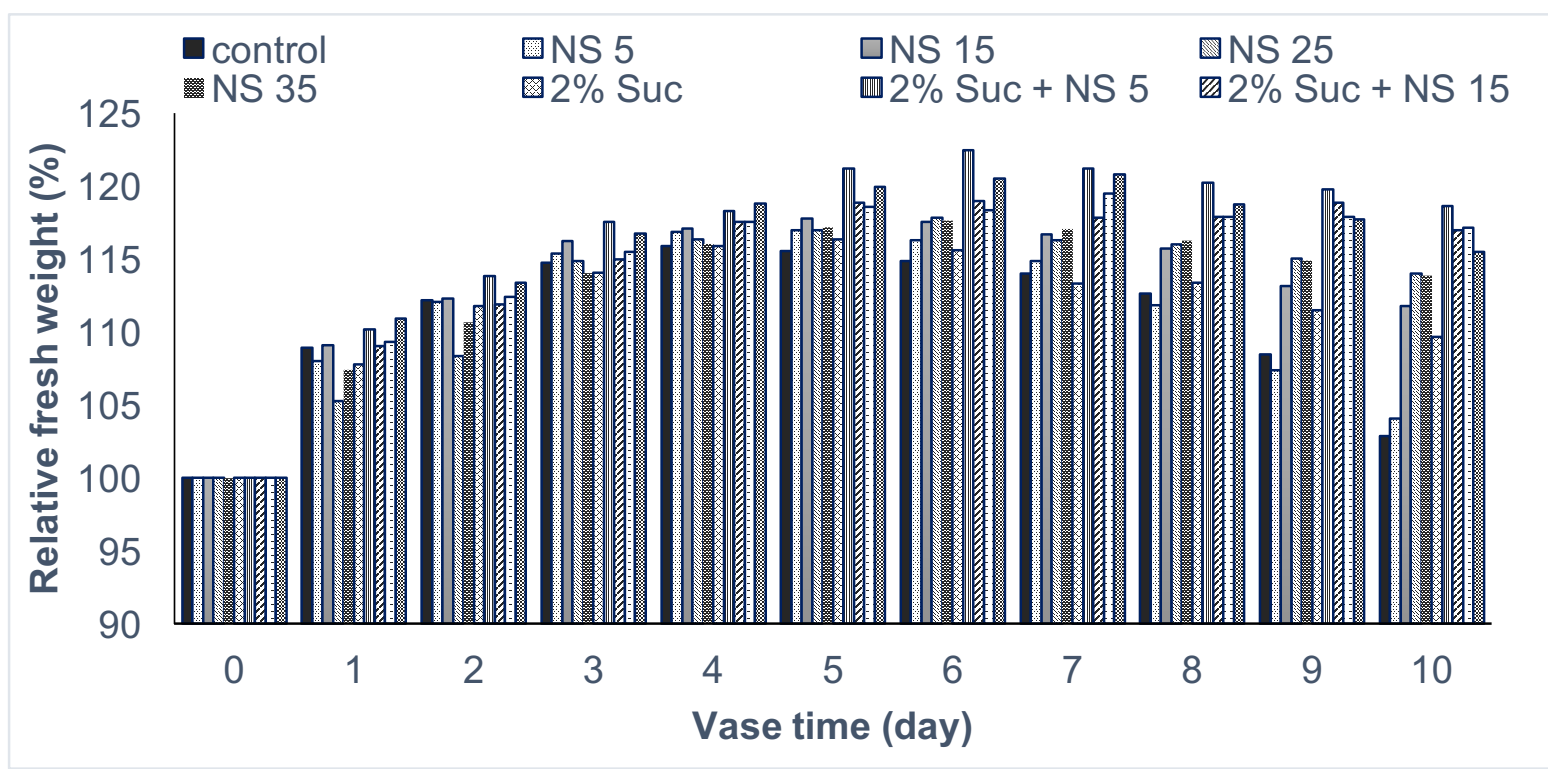

Figure 9. Relative fresh weight variation after 10 days of carnation vase life of the control (filtered water), the filtered wateradded SNPs $(5,15,25$, and $35 \mathrm{ppm})$, and the filtered water-added SNPs $(5,15,25$, and $35 \mathrm{ppm})$ with $2 \%$ sucrose.

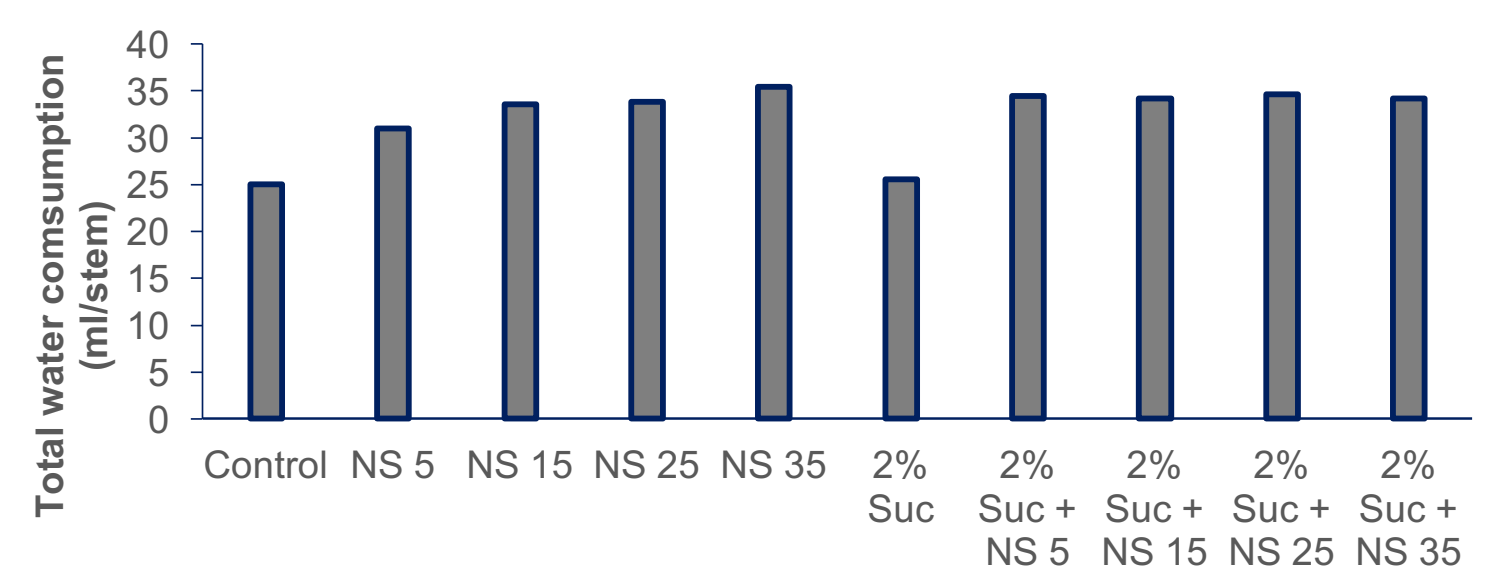

Axis Title

Figure 10. Vase solution uptake rate after 10 days of carnation vase life of the control (filtered water), filtered water added SNPs $(5,15,25$, and $35 \mathrm{ppm})$, filtered water-added SNPs $(5,15,25$, and $35 \mathrm{ppm})$ with $2 \%$ sucrose. 
Day 0

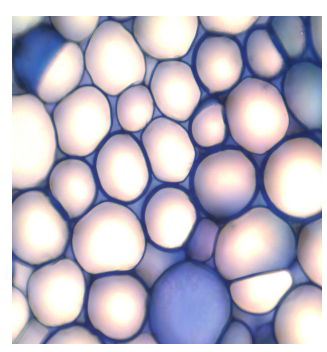

B

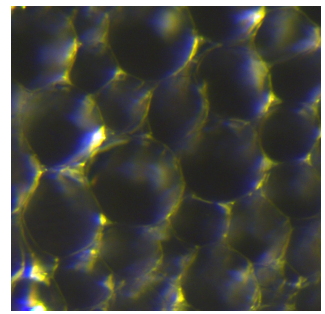

Control
Day $10^{\text {th }}$
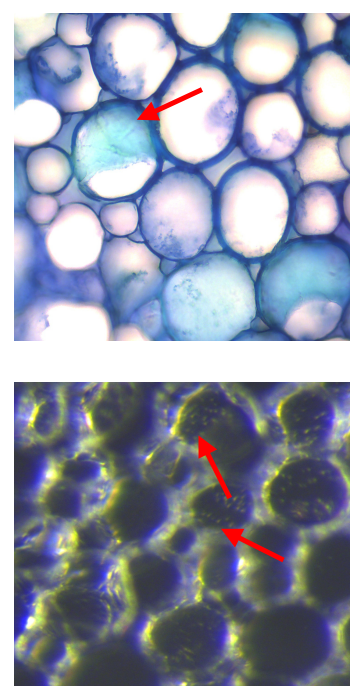

Control
Day $10^{\text {th }}$
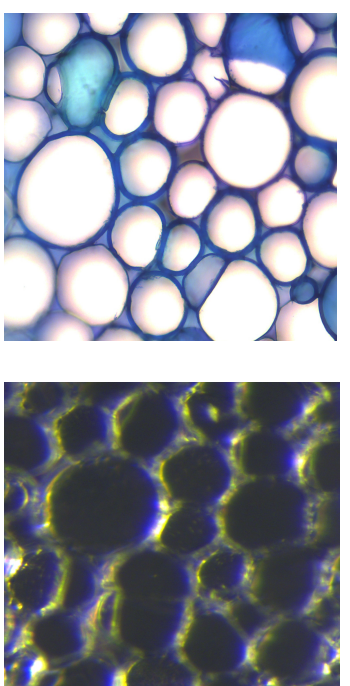

SNPs of $5 p p m$
Day $10^{\text {th }}$
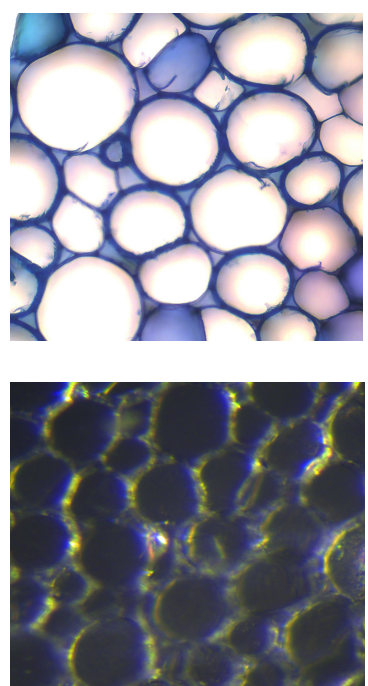

SNPs of $5 p p m+2 \%$ sucrose

Figure 11. Morphology of the cut flower stem surface of carnation: (A) using optical microscope, (B) using stereo microscope, Red arrows: blockage.

\section{Flower diameter}

There were statistically significant differences in term of the diameter of inflorescences between the treatments with SNPs with the control $(\mathrm{P} \leq 0.05)$ (Figure 12). In this study, application SNPs with sucrose improved the diameter of carnation cut flowers. It could be observed from the data that the low concentration of SNPs of 5 ppm with sucrose favored the inflorescence opening. When the SNP concentrations increased, the flower diameter declined. SNPs at the higher concentrations may have the toxicity effect on the inflorescence.

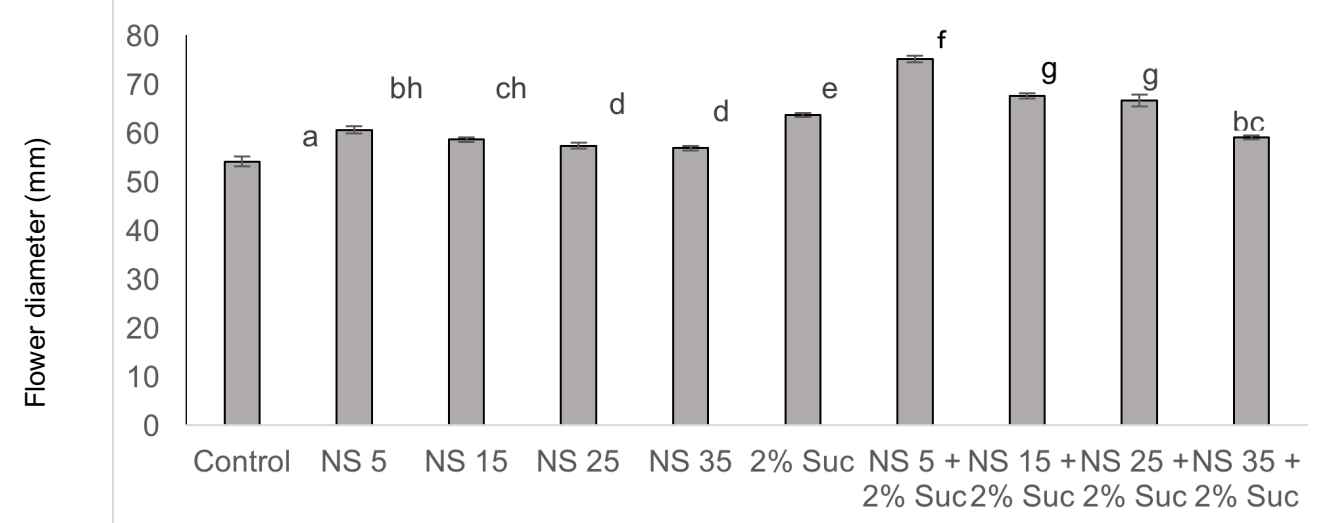

Figure 12. Effect of SNPs $(P \leq 0.05)$ after 10 days on the inflorescence opening of carnation flowers of the control (filtered water), filtered water-added SNPs $(5,15,25$, and $35 \mathrm{ppm})$, filtered water-added SNPs $(5,15,25$, and $35 \mathrm{ppm})$ with $2 \%$ sucrose. 
Many studies reported on the extending vase life ability of sucrose (Paulin, Jamain, 1982; Ichimura, Hiraya, 1999). Sucrose plays as an energy source (Moalem-Beno et al., 1993), osmotic regulator (Bieleski et al., 1993), thereby playing a role in flower opening and water balance regulation (Kuiper et al., 1995). However, sucrose may promote the bacterial growth. Thus, vase solutions containing a carbohydrate supply like sucrose with an antimicrobial substance to maximize vase life is a promising method. When supplement sucrose with SNPs in the vase solutions, not only the vase time and relative fresh weight were improved, the flower diameters increased, as well. Nevertheless, when SNP concentrations increased, this efficacy altered. Even comparing to the control, all the treatments revealed a statistically greater in flower diameter, the consideration reduction in the flower diameter was observed when increased the SNP concentration from 5 to $15,25,35 \mathrm{ppm}$.

\section{Bacterial counts}

Bacteria in the vase solutions and in the basal 3 $\mathrm{cm}$ from the stem ends was investigated on the $10^{\text {th }}$ day. Significant difference in number of bacteria in the vase solutions and the stems was observed between the control and the SNP treatments with and without sucrose (Figure 13). The number of bacteria in treatment of sucrose only was the highest. This evidence proves that sucrose not only prolongs the vase life but also promotes the bacterial growth that inhibits the water uptake of cut flowers. Van-Doorn and Perik (1990) reported that bacteria in vase solutions and in stems was responsible for xylem occlusion, releasing toxic such as metabolites or enzymes, producing ethylene, thus led to inducing the senescence and shortening the vase life.

The lower bacteria in the vase solutions and stems suggested that supplement of SNPs inhibited the bacterial growth. SNPs caused cell damage, preventing cell division (Liu et al., 2009, Morones et al., 2005), and inhibiting the forming of biofilm (Ibrahim, 2015). Vascular occlusion has been caused by microbial proliferation (Van Doorn et al., 1995). The antibacterial activity of SNPs is well established. In this study, SNPs inhibited the bacterial growth and therefore could prolong carnation cut flower longevity.

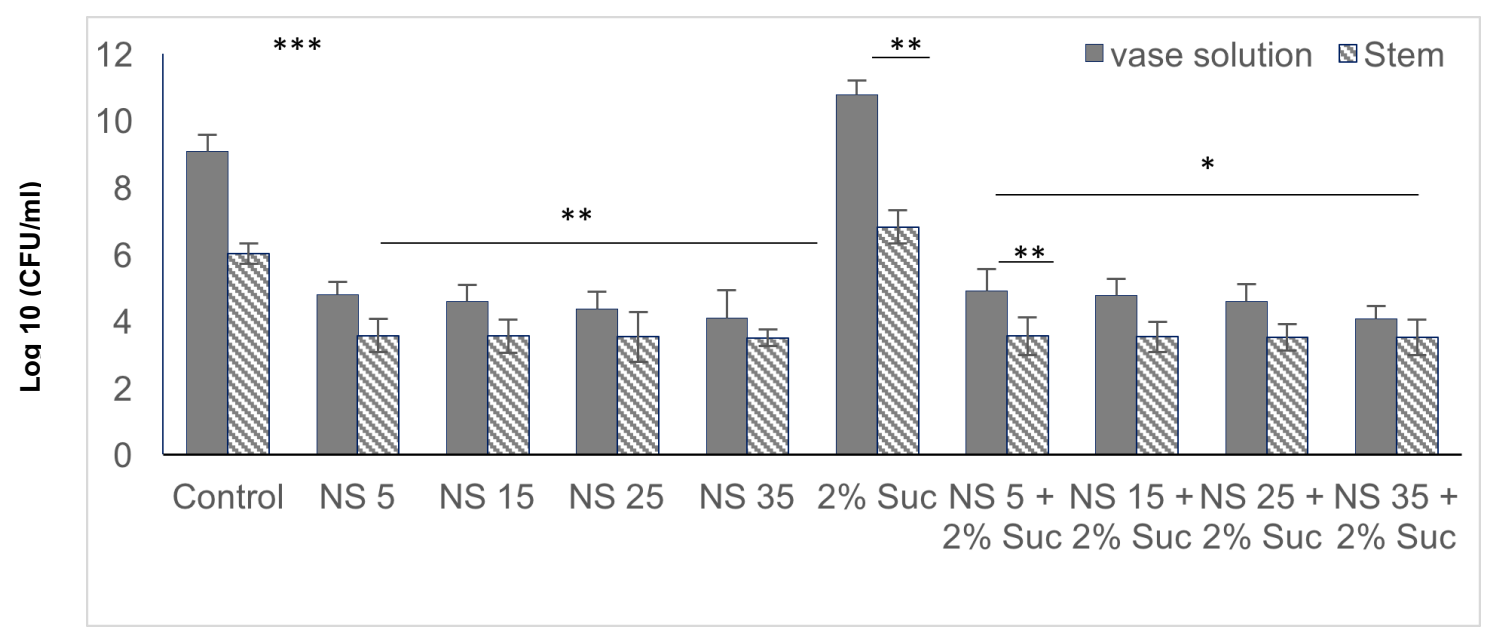

Figure 13. Changes for SNPs in number of bacteria after 10 days in the stem end and vase solutions of the control (filtered water), added SNPs $(5,15,25$, and $35 \mathrm{ppm})$, added SNPs $(5,15,25$, and $35 \mathrm{ppm})$ with $2 \%$ sucrose ; ${ }^{*} \mathrm{P} \leq 0.05 ;{ }^{* *} \mathrm{P} \leq 0.01$; ${ }^{* * *} \mathrm{P} \leq 0.001$.

\section{CONCLUSION}

In conclusion, a simple and rapid procedure for bio-synthesis of SNPs through $A$. pinto extracts was developed. Various reaction conditions were investigated to obtain the optimum reaction conditions including $180 \mathrm{~min}$ of reaction time at $50^{\circ} \mathrm{C}$ and $\mathrm{pH} 11$. Bio-synthesis at the optimum conditions yielded $0.5195 \mathrm{mg} / \mathrm{mL}$. The SNPs were spherical and oblong in shape. In addition, the 
calculated particle size of the SNPs from the TEM histogram particles distribution ranged from 5 to 65 $\mathrm{nm}$. Among the treatments, the combination of SNPs 5ppm applied with $2 \%$ sucrose was the best in term of vase life, maitaining the water uptake, relative fresh weight and also flower diameter. SNPs could be used as a promising preservative agent for improving the postharvest quality of carnation cut flowers. These results suggest the possibility of the use of SNPs as an antibacterial agent to made full advantages of sucrose in extending vase life.

\section{REFERENCES}

Ahmed S, Saifullah, Ahmad M, Swami B, Ikram S (2016) Green synthesis of silver nanoparticles using Azadirachta indica aqueous leaf extract. J Radiat Res Appl Sci 9: 1-7.

Alaey M, Babalar M, Naderi R, Kafi M (2011) Effect of pre- and postharvest salicylic acid treatment on physiochemical attributes in relation to vase-life of rose cut flowers. Postharvest Biol Technol 61: 91-94.

Arrom L, Munne-Bosch S (2012) Sucrose accelerates flower opening and delays senescence through a hormonal effect in cut lily flowers. Plant Sci 188: 41-47.

Ball RC, Weitz DA, Witten TA, Leyvraz F (1987) Universal kinetics in reaction-limited aggregation. Phys Rev Lett 58: 274-277.

Basavaraj D, Hermla BN (2014) Economics and profitability in carnation (Dianthus caryophyllus 1.) Influenced by integrated nutrient. Int J Agric Sci Vet Med 2: 39-41.

Beni AM, Abdolla H, Ali N, Mahmud G, Mohammad Z (2013) Improving physiological quality of cut tuberose (Polianthes tuberosa cv. Single) flowers by continues treatment with humic acid and nano-silver particles. $J$ Ornam Hortic Plants 3: 133-141.

Birla SS, Gaikwad SC, Gade AK, Rai MK (2013) Rapid synthesis of silver nanoparticles from Fusarium oxysporum by optimizing physicocultural conditions. Sci World J 2013: 1-12.

Moalem-Beno D, Tamari G, Leitner-Dagan Y, Borochov A, Bieleski RL (1993) Fructan hydrolysis drives petal expansion in the ephemeral daylily flower. Plant Physiol 103: 213-219.

Bogireddy NKR, Kiran Kumar HA, Mandal BK (2016) Biofabricated silver nanoparticles as green catalyst in the degradation of different textile dyes. J Environ Chem Eng 4: $56-64$

Bowyer MC, Wills RBH, Badiyan D, Ku V (2003) Extending the postharvest life of carnations with nitric oxide -Comparison of fumigation and in vivo delivery. Postharvest Biol Technol 30: 281-286.

Buttner D, Bonas U (2010) Regulation and secretion of Xanthomonas virulence factors. FEMS Microbiology Reviews 34: 107-133.

Cab Jiménez FEC, Enríquez QJF, Pérez PJ, Hernández GA, Herrera HJG, Ortega JE, Quero CAR (2008) Forage production in three Brachiaria species as a single crop or in association with Arachis pintoi in Isla. Veracruz Tec Pecu Méx 46: 317-332.

Carrillo-López LM, Morgado-González A, MorgadoGonzález A (2016) Biosynthesized silver nanoparticles used in preservative solutions for Chrysanthemum cv. Puma. J Nanomater 2016: 1-10.

Chen WS, Liao LJ, Chen CY, Huang KL (2001) Kinetin, gibberellic acid, and sucrose affect vase life in Oncidium spp. Acta Bot Gallica 148: 177-181.

Cook BG, Pengelly BC, Brown, SD, Donnelly JL, Eagles DA, Franco MA, Hanson J, Mullen BF, Partridge IJ, Peters M, Schultze-Kraft R (2005) Tropical forages. CSIRO, DPI\&F(Qld), CIAT and ILRI, Brisbane, Australia

Da Silva JAT (2003) The cut flower: postharvest condiderations. Online J Biol Sci 3: 406-442.

Dinesh S, Karthikeyan S, ArumugamP (2012) Biosynthesis of silver nanoparticles from Glycyrrhiza glabra root extract. Arch Appl Sci Res 4: 178-187.

De Sousa-Machado IB, Felippe T, Garcia R, Pacheco G, Moreira D, Mansur E (2018) Total phenolics, resveratrol content and antioxidant activity of seeds and calluses of pinto peanut (Arachis pintoi Krapov. \& W.C. Greg.). Plant Cell Tissue Organ Cult 134: 491-502.

Dipankar C, Murugan S (2012) The green synthesis, characterization and evaluation of the biological activities of silver nanoparticles synthesized from Iresine herbstii leaf aqueous extracts. Colloids Surfaces B Biointerfaces 98: 112-119.

Dwivedi AD, Gopal K, (2010) Biosynthesis of silver and gold nanoparticles using Chenopodium album leaf extract. Colloids Surfaces A Physicochem Eng Asp 369: 27-33.

Edrisi B, Sadrpoor A, Saffari VR (2011) Effects of Chemicals on Vase Life of Cut Car (Dianthus caryophyllus L.'Delphi') and Microorganisms Population in Solution. Journal Ornam Hortic Plants 2: 1-11.

Feng QL, Wu J, Chen GQ, Cui FZ, Kim TN, Kim JO (2000) A mechanistic study of the antibacterial effect of silver ions on Escherichia coli and Staphylococcus aureus. $J$ Biomed Mater Res 52: 662-668.

Ferrante A, Hunter DA, Wesley PH, Reid MS (2002) Thidiazuron - a potent inhibitor of leaf senescence in Alstroemeria. Postharvest Biol Technol 25: 333-338. 
Gan PP, Ng SH, Huang Y, Li SFY (2012) Green synthesis of gold nanoparticles using palm oil mill effluent (POME): A low-cost and eco-friendly viable approach. Bioresour Technol 113: 132-135.

Gao Z, Gao F, Shastri KK, Zhang B (2016) Frequency selective propagation of localized spoof surface Plasmon in a graded plasmonic resonator chain. Sci Rep 25576: 1-6.

Galbally, J., Galbally, E. (1997) Carnations and pinks for garden and greenhouse. Timber Press, Portland, Oregon, USA.

Grosso NR, Nepote V, Guzmán CA (2000) Chemical composition of some wild peanut species (Arachis L.) seeds. J Agric Food Chem 48: 806-809.

Hamed CS, Arab M, Roozban MR, Ahmadi N (2013) Postharvest longevity and quality of cut carnations, "Pax" and "Tabor", as affected by silver nanoparticles. Acta Horticulturae 1012: 527-532.

Hamidimoghadam E, Rabiei V, Nabigol A, Javad F (2014) Postharvest Quality Improvement of Carnation (Dianthus caryophyllus L .) Cut Flowers by Gibberellic Acid, Benzyl Adenine and Nano Silver. Agric Commun 2: 28-34.

Hashemabadi D (2014) The role of silver nano-particles and silver thiosulfate on the longevity of cut carnation (Dianthus caryophyllus) flowers. J Environ Biol 35: 661666.

Hatami M, Hatamzadeh A, Ghasemnezhad M, Ghorbanpour M (2013) The comparison of antimicrobial effects of silver nanoparticles (snp) and silver nitrate (agno 3 ) to extend the vase life of "red ribbon" cut rose flowers. Trakia J Sci 11: 144-151.

He S, Joyce DC, Irving DE, Faragher, JD (2006) Stem end blockage in cut Grevillea "Crimson Yul-lo" inflorescences. Postharvest Biol Technol 41: 78-84.

Henglein A (1993) Physicochemical properties of small metal particles in solution: "Microelectrode" reactions, chemisorption, composite metal particles, and the atom-tometal transition. $J$ Physic Chem 97: 5457-5471.

Hoeberichts FA, van Doorn WG, Vorst O, Hall RD, van Wordragen MF (2007) Sucrose prevents up-regulation of senescence-associated genes in carnation petals. $J$ Exp Bot 58: $2873-2885$.

Hutchinson M, Chebet D, Emongor V (2004) Effect of accel, sucrose and silver thiosulphate on the water relations and post-harvest physiology of cut tuberose flowers. African Crop Science Journal 11: 279-287.

Ibrahim HMM (2015) Green synthesis and characterization of silver nanoparticles using banana peel extract and their antimicrobial activity against representative microorganisms. J Radiat Res Appl Sci 8: 265-275.
Ichimura K, Hiraya T (1999) Effect of siver thiosulfate complex (STS) in combination with sucrose on the vase life of cut sweet pea flowers. J Japan Soc Hort Sci 68: 2327.

Ichimura K, Suto K (1999) Effects of the time of sucrose treatment on vase life, soluble carbohydrate concentrations and ethylene production in cut sweet pea flowers. Plant Growth Regul. 28: 117-122.

Jiang H, Moon KS, Zhang Z, Pothukuchi S, Wong CP (2006) Variable frequency microwave synthesis of silver nanoparticles. J Nanopart Res 8:117-124.

Jowkar MM, Khalighi A, Kafi M, Hassanzadeh N (2013) Evaluation of aluminum sulfate as vase solution biocide on postharvest microbial and physiological properties of "Cherry Brandy" rose. Acta Horticulturae 1012: 615-626.

Jurgens A, Witt T, Gottsberger G (2003) Flower scent composition in Dianthus and Saponaria species (Caryophyllaceae) and its relevance for pollination biology and taxonomy. Biochem Syst Ecol 31: 345-357.

Khalil MMH, Ismail EH, El-Baghdady KZ, Mohamed D (2014) Green synthesis of silver nanoparticles using olive leaf extract and its antibacterial activity. Arab J Chem 7: 1131-1139.

Khamseekhiew B, Liang JB, Wong CC, Jalan ZA (2001) Ruminal and intestinal digestibility of some tropical legume forages. Asian-Aust J Anim Sci 14: 321-325.

Kim JH, Min BR, Kim HS, Won J, Kang YS (2003) Facilitated transport of ethylene across polymer membranes containing silver salt: Effect of $\mathrm{HBF}_{4}$ on the photoreduction of silver ions. J Memb Sci 212: 283-288.

Kim JH, Lee AK, Suh JK (2005) Effect of certain pretreatment substances on vase life and physiological character in lilium spp. Acta Horticulturae 673: 307-314.

Kuiper D, Ribot S, van Reenen HS, Marissen N (1995) The effect of sucrose on the flower bud ripening of Madelon cut roses. Sci Hort 60: 325-336.

Lopes RM, Da Silveira Agostini-Costa T, Gimenes MA, Silveira D (2011) Chemical composition and biological activities of Arachis species. J Agric Food Chem 58: 43214330 .

Loubaud M, Van Doorn WG (2004) Wound-induced and bacteria-induced xylem blockage in rose, Asyiba and Vibrium. Postharvest Biol Technol 32: 281-288.

Li H, Huang X, Li J, Liu J, Joyce D, He S (2012) Efficacy of nano-silver in alleviating bacteria-related blockage in cut rose cv. Movie Star stems. Postharvest Biol Technol 74: $36-41$.

Liu J, Zhang Z, Joyce DC, He S., Cao J, Peitao LV (2009a) Effects of postharvest nano-silver treatments on cut-flowers. Acta Horticulturae 847: 245-250. 
Liu J, He S, Zhang Z, Cao J, Peitao LV, He S, Cheng G., Joyce DC (2009b) Nano-silver pulse treatments inhibit stem-end bacteria on cut gerbera cv. Ruikou flowers. Postharvest Biol Technol 54: 59-62.

Logaranjan K, Raiza AJ, Gopinath SCB, Chen Y, Pandian K (2016) Shape- and Size-Controlled Synthesis of Silver Nanoparticles Using Aloe vera Plant Extract and Their Antimicrobial Activity. Nanoscale Res Lett 11: 520-529.

Lu P, He S, Li H, Cao J, Xu H (2010a) Effect of nano silver treatment on vase life of cut rose cv. Movie Star flowers. J Food Agric Environ 8: 1118-1122.

Lu P, Cao J, He S, Liu J, Li H, Cheng G, Ding Y, Joyce DC (2010b) Nano-silver pulse treatments improve water relations of cut rose cv. Movie Star flowers. Postharvest Biol Technol 57: 196-202.

Medda S, Hajra A, Dey U, Bose P, Mondal NK (2015) Biosynthesis of silver nanoparticles from Aloe vera leaf extract and antifungal activity against Rhizopus sp. and Aspergillus sp. Appl Nanosci 5: 875-880.

Morones JR, Elechiguerra JL, Camacho A, Holt K, Kouri JB, Ramírez JT, Yacaman MJ (2005) The bactericidal effect of silver nanoparticles. Nanotechnology 16: 23462353.

Mukherjee P, Ahmad A, Mandal D, Senapati S, Sainkar SR, Khan MI, Renu P, Ajaykumar PV, Alam M, Kumar R, Sastry M (2001) Fungus-mediated synthesis of silver nanoparticles and their immobilization in the mycelial matrix: A novel biological approach to nanoparticle synthesis. Nano Lett 1: 515-519

Mutui TM, Emongor VE, Hutchinson MJ (2001) Effect of accel on the vase life and postharvest quality of alstroemeria (Alstroemeria aurantica L.) cut flowers. Afr $J$ Sci Technol 2: 82-88.

Nell TA (1992) Taking silver safely out of the longevity picture. Grower Talks June 35: 41-42.

Nemati SH, Esfandiari B, Rezaei A (2013) Improvement of vase life and postharvest factors of Lilium orientalis 'bouquet' by silver nano particles. Scientia Notulae Biologicae 5: 490-493.

Nowak J, Rudnicki RM (1990) Postharvest Handling and Storage of Cut Flower, Florist, Greens and Potted Plants. Timber Press Inc.

Ohkawa K, Kasahara Y, Suh JN (1999) Mobility and effects on vase life of silver-containing compounds in cut rose flowers. Hort Science 34: 112-113.

Patra JK, Baek KH (2017) Antibacterial activity and synergistic antibacterial potential of biosynthesized silver nanoparticles against foodborne pathogenic bacteria along with its anticandidal and antioxidant effects. Front Microbiol 8: 167-171.
Paulin A, Jamain C (1982) Development of flowers and changes in various sugars during opening of cut carnations. J Amer Soc Hort Sci 107: 258-261.

Put HMC (1990) Micro-organisms from freshly harvested cut flower stems and developing during the vase life of chrysanthemum, gerbera and rose cultivars. Nanoscale Res Lett 43: 129-144.

Rahman MM, Ahmad SH, Lgu KS (2012) Psidium guajava and piper betle leaf extracts prolong vase life of cut carnation (Dianthus caryophyllus) flowers. Sci World $J$ 2012: $1-9$.

Raja S, Ramesh V, Thivaharan V (2017) Green biosynthesis of silver nanoparticles using Calliandra haematocephala leaf extract, their antibacterial activity and hydrogen peroxide sensing capability. Arab $\mathrm{J}$ Chem 10: 253-261.

Safa Z, Hashemabadi D, Kaviani B (2012) Improving the Vase Life of Cut Gerbera (Gerbera jamesonii L. cv. 'Balance') Flower with Silver Nano-particles. Eur J Exp Biol 2: 2489-2492.

Saion E, Gharibshahi E, Naghavi K (2013) Size-controlled and optical properties of monodispersed silver nanoparticles synthesized by the radiolytic reduction method. Int J Mol Sci 14: 7880-7896.

Salmond GPC (1994) Secretion of extracellular virulence factors by plant pathogenic bacteria. Annu Rev Phytopathol 32: 181-200.

Shankar SS, Rai A, Ahmad A, Sastry M (2004) Rapid synthesis of $\mathrm{Au}, \mathrm{Ag}$, and bimetallic $\mathrm{Au}$ core-Ag shell nanoparticles using Neem (Azadirachta indica) leaf broth. J Colloid Interface Sci 275: 496-502.

Sang SY, Jamharee F, Prasad KN, Azlan A, Maliki N (2014). Influence of drying treatments on antioxidant capacity of forage legume leaves. J Food Sci Technol 51: 988-983.

Solgi M, Kafi M, Taghavi TS, Naderi R (2009) Essential oils and silver nanoparticles (SNP) as novel agents to extend vase-life of gerbera (Gerbera jamesonii cv. 'Dune') flowers. Postharvest Bio. Technol 53: 155-158.

Solgi M, Kafi M, Taghavi TS, Naderi R, Eyre JX, Joyce DC (2011) Effects of silver nanoparticles (SNP) on Gerbera jamesonii cut flowers. Int J Postharvest Technol Innov 2: 274-285.

Traiwatcharanon P, Timsorn K, Wongchoosuk C (2017) Flexible room-temperature resistive humidity sensor based on silver nanoparticles. Mater Res Express 4.

Usha RP, Rajasekharreddy P (2011) Green synthesis of silver-protein (core-shell) nanoparticles using Piper betle L. leaf extract and its ecotoxicological studies on Daphnia 
magna. Colloids Surfaces A Physicochem Eng Asp 389: 188-194.

Van Doorn WG (2012) Water relations of cut flowers: An update. Hortic.। Rev (Am Soc Hortic Sci 18: 55-106.

Van Doorn WG, de Witte Y, Harkema H (1995) Effect of high numbers of exogenous bacteria on the water relations and longevity of cut carnation flowers. Postharvest Biol Technol 6: 111-119.

Van Doorn WG, Zagory D, de Witte Y, Harkema H (1991) Effects of vase-water bacteria on the senescence of cut carnation flowers. Postharvest Biol Technol 1: 161-168.

Van Meeteren U (1992) Role of air embolism and low water temperature in water balance of cut chrysanthemum flowers. Scientia Hortic 51, 275-284.

Vanaja M, Annadurai G (2012) Coleus aromaticus leaf extract mediated synthesis of silver nanoparticles and its bactericidal activity. Appl Nanosci 3: 217-223.

Verlinden S, Garcia JJV (2004). Sucrose loading decreases ethylene responsiveness in carnation (Dianthus caryophyllus cv.White Sim) petals. Postharvest Biol Technol 31: 305-312.
Verma A, Mehata MS (2016) Controllable synthesis of silver nanoparticles using Neem leaves and their antimicrobial activity. J Radiat Res Appl Sci 9: 109-115.

Williamson VG, Parsons S, Franz P (2002) Inhibiting the Postharvest Wounding Response in Wildflowers. Rural Indus Res Dev Corpor 82: 23-29.

Weiss D (1997) Sugar-dependent gibberellin-induced chalcone synthase gene expression in Petunia corollas. Plant Physiol 13:419-424.

Yasin S, Liu L, Yao J (2013) Biosynthesis of Silver Nanoparticles by Bamboo Leaves Extract and Their Antimicrobial Activity. J Fiber Bioeng. Informatics 6: 77-84.

Raja S, Ramesh V, Thivaharan V (2017) Green biosynthesis of silver nanoparticles using Calliandra haematocephala leaf extract, their antibacterial activity and hydrogen peroxide sensing capability. Arab J Chem 6: 223-233.

Zhang C, Liu M, Fu J, Wang Y, Dong L (2012) Exogenous sugars involvement in senescence and ethylene production of tree peony 'Luoyang Hong' cut flowers. Korean J Hortic Sci Technol 30: 718-724.

\title{
TỔNG HỢP NANO BAC TÙ DICH CHIẾT LÁ CÂY CỎ ĐÂU ARACHIS PINTOI NHẦM NÂNG CẢO CHẤT LỰ̛̣G SAU THU HOẠCH CỦA HOA CẨM CHƯỚNG (DIANTHUS CARYOPHYLLUS L.) CẮT CÀNH
}

\author{
Tran Lap Xuan, Le Ba Le, Le Thi Anh Tu \\ Đại học Đà Lạt, Tỉnh Lâm Đồng, Việt Nam
}

\section{TÓM TẮT}

Nano bạc được tổng hợp từ dịch chiết lá cây cỏ đậu Arachis pintoi Krapov. \& W.C. Greg. Nguyên liệu đầu vào được chuẩn bị như sau: hấp $20 \mathrm{~g}$ lá tươi ở $121^{\circ} \mathrm{C}, 15 \mathrm{psi}, 15$ phút, và sử dụng $4 \mathrm{mM}$ bạc nitrat (AgNO3). Điều kiện tổng hợp nano bạc được thử nghiệm với thời gian sinh tổng hợp $(5,30,60,90,120,150$, và 180 phút), nhiệt độ phản ứng $\left(10,20,30,40\right.$, và $\left.50^{\circ} \mathrm{C}\right)$ và $\mathrm{pH}$ của dung dich $(1,3,5,7,9$, và 11$)$. Kết quả cho thấy, hiệu quả tạo nano bạc tốt nhất tại $50^{\circ} \mathrm{C}, \mathrm{pH} 11$, sau 180 phút phản ứng sinh tồng hợp. Các hạt nano thu được có dạng hình cầu và hình thuôn dài với kích thước trung bình $26,4 \mathrm{~nm}$. Dung dịch nano bạc với các nồng độ $5,15,25$ và 35 ppm có bổ sung hoặc không bổ sung $2 \%$ sucrose được thử nghiệm trên hoa cẩm chướng cắt cành cho thấy kéo dài thời gian tươi, đường kính hoa và tỷ lệ tăng trọng lượng tươi của cành hoa tương ứng với tốc độ hấp thụ dung dịch nước cắm hoa. Nano bạc đã ức chế đáng kể sự phát triển của vi khuẩn trong cành hoa và dung dịch cắm hoa, dẫn đến hạn chế sự tắc nghẽn trong cành hoa. Dung dịch cắm hoa chứa $5 \mathrm{ppm}$ nano bạc có bổ sung $2 \%$ sucrose có hiệu quả tốt nhất trong bảo quản hoa cẩm chướng cắt cành sau thu hoạch. Kết quả ghi nhận, nano bạc sinh tổng hợp từ dịch chiết lá cây cỏ đậu có thể được sử dụng làm chất bảo quản cho hoa cẩm chướng cắt cành.

Tù̀ khoá: Arachis pintoi, bảo quản, cẩm chướng cắt cành, nano bạc, sinh tổng hợp 